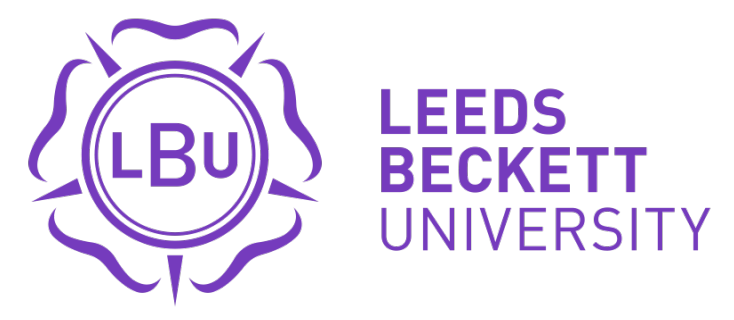

Citation:

Burroughs, RM (2015) Slave-trade suppression and the culture of anti-slavery in nineteenth-century Britain. In: The suppression of the Atlantic slave trade: British policies, practices and representations of naval coercion. Manchester University Press. ISBN 978-0-7190-8511-6

Link to Leeds Beckett Repository record:

https://eprints.leedsbeckett.ac.uk/id/eprint/1699/

Document Version:

Book Section (Accepted Version)

(C) Manchester University Press - uploaded by permission

The aim of the Leeds Beckett Repository is to provide open access to our research, as required by funder policies and permitted by publishers and copyright law.

The Leeds Beckett repository holds a wide range of publications, each of which has been checked for copyright and the relevant embargo period has been applied by the Research Services team.

We operate on a standard take-down policy. If you are the author or publisher of an output and you would like it removed from the repository, please contact us and we will investigate on a case-by-case basis.

Each thesis in the repository has been cleared where necessary by the author for third party copyright. If you would like a thesis to be removed from the repository or believe there is an issue with copyright, please contact us on openaccess@leedsbeckett.ac.uk and we will investigate on a case-by-case basis. 
III. Representations 
6. Slave-trade suppression and the culture of anti-slavery in nineteenth-century Britain Robert Burroughs

Introduction

With the culmination of the West Indian emancipation movement in 1838, politicians and anti-slavery leaders turned their attention increasingly to slave-trade suppression. ${ }^{1}$ Public interest in, if not support for, the cause was roused, as from the late 1830s until the early 1850s--especially in the 1840s when its efficacy became the subject of political debate- the African Squadron was the topic of countless newspaper and periodical articles, and tens of pamphlets. ${ }^{2}$ It further attracted description and commentary, often of an expansive and colourful character, in travelogues and memoirs, and a handful of fictional texts. The authors working in these different literary forms varied greatly in terms of their social background, political views, the extent of their technical knowledge, and their rationale for writing about the matter. Nor was the focus of their discussion uniform: while some firsthand officers of wide-ranging experience described its many elements, the majority of writings on naval suppression were slanted toward one geographical region of activity, or particular aspects of the work and its outcomes, according to authors' expertise or readers’ interest, or both. A number of accounts by missionaries resident in Sierra Leone centre upon the Liberated Africans Department at Freetown, for example, whereas officers involved in signing antislave-trade treaties with local traders and potentates catered for the public interest in narratives of travel in West Africa. Reports by naval surgeons are unsurprisingly dominated by descriptions of the climatic conditions in the so-called 'White Man’s Grave’ of West Africa, and the impact of these upon crews. ${ }^{3}$

Of all these subjects and locales, it was the seaborne actions that figured most prominently in creating a picture of naval suppression in in the mind's eye of the reading 
public. Even though many testified that offshore patrolling of the West African coast was mostly tedious and unrewarding work, authors of published eyewitness accounts joined writers of fictional narratives in focusing upon episodes of danger and excitement at sea likely to arouse their readers' curiosity and sympathy: chases of and battles with slave ships; shipboard interactions with slave traders and their captives; perilous cruises to shore in dilapidated prize vessels; outbreaks of disease, and the death of British sailors. It might seem natural that reports of this work at the coal-face of Britain's anti-slave-trade policy should take centre-stage in its cultural dissemination. Regency Britain witnessed a rise in esteem for the gentleman-officer of the navy--above all, Nelson, who was enshrined, following his death, as the embodiment of imperial duty and sacrifice ${ }^{4}$--which would seem to have guaranteed admiration for patrollers of the slave trade. But when it is considered that eminent lords of the Admiralty and naval officers, not least Nelson, had until 1807 protected the British slave trade, in line with the navy's remit to defend national mercantile interests, it becomes apparent that the construction of positive imagery of naval suppression was part of a process of re-identification of Britain as a nation opposed to the slave trade and, later, slavery in the Americas. The ease of the changeover from the leading profiteers of the human traffic to its pre-eminent opponents cannot be assumed.

In this chapter I examine this transition in national self-perception, and demonstrate that as well as inspiring much patriotic and religious fanfare, naval suppression also was a thorny and divisive topic. In both fictional and non-fictional written representations of the recapture of enslaved Africans at sea critics of the campaign highlighted what they saw as the failings of Britain’s abolitionist policies, and cast doubt upon the moralistic and spiritual arguments which are encoded in writings by the supporters of naval suppression. The Royal Navy's mission to eliminate the Atlantic slave trade helped to keep alive a culture of antislavery in nineteenth-century Britain, but its place in the hearts and minds of the people that 
created that culture was never secure. The rise of racial sciences is one notable cause and symptom of the decline in support for the campaign towards the middle of the century. The following two section of this chapter analyse in turn a range of celebratory and critical representations of the African Squadron, connecting these to contemporary debates on nation and empire, class, gender and race. To begin, I examine celebratory images of the patrols within the religious and moralistic frameworks of writing about slavery and travel at sea.

\section{Writing redemption}

To understand how representations of naval suppression suggested the moral and spiritual redemption of the nation, it is profitable to read them in the broader discursive context of the sea voyage. As with their Romantic-era forebears, Victorian writers took great interest in tales of maritime peril and mishap. Narratives of hazardous travel at sea provided more than simple entertainment in the suffering of others; they also projected, and sometimes challenged, social and political identities. For people still persuaded by religious explanations of chance and accident, the perilous sea voyage stood metaphorically for the providential vulnerability of all human life, in which faith in God was essential. Disasters were taken as evidence of supernatural punishment, whereas epic tales of survival suggested divine intervention on behalf of the endangered seafarer. Narratives of seaborne danger assumed social and political significance because the religion, or religious fervour, nationality, gender, social rank and racial identities of mariners were reckoned with to account for their endurance or destruction. Frequently tales of shipwreck operated to consolidate the existing order by attributing the hand of God to the survival of those in positions of authority on ships. At other times, their typically small cast of socially diverse individuals battling against the elements enabled writers of shipwreck narratives to explore areas of tension and ambiguity in social relations. ${ }^{5}$ 
Representations of the Middle Passage frequently employ such metaphoric interpretations of disaster and survival at sea, and the spiritual autobiographies of John Newton (1725-1807) epitomise them. Newton was a slave-ship sailor and then captain who in later life became an evangelical crusader and public critic of the slave trade. In his youth he suffered impressment by the Royal Navy, and was himself enslaved while seeking refuge from what he vaguely termed his own 'passions and follies' on West Africa’s Windward coast. But the religious awakening that led him eventually to condemn the slave trade began, according to Newton's own testimonies, when, in 1748, his ship was caught in a violent storm on the home leg of a slaving voyage. He attributed his survival to 'the good providence of God [which] ... delivered me from those scenes of wickedness and woe'. ${ }^{6}$ Having been spared death, he described himself as conscience-bound to expose the evils of transatlantic slavery (although he continued to trade in slaves for a few years after the storm).

'Perhaps what I have said of myself may be applicable to the nation at large', wrote Newton. ${ }^{7}$ His testimonies would indeed be incorporated into abolition discourses which conceived of the slave trade as a national sin. ${ }^{8}$ The divinely ordained wrecking of the slave trader figured in abolitionist texts such as William Cowper’s 'The Negro’s Complaint' (1788), and James Montgomery’s ‘The Voyage of the Blind’ (1824), as well as in J.W.M. Turner's famous Slavers throwing overboard the Dead and Dying - Typhon [sic] coming on (1840). As Newton put it, 'It is Righteousness that exalteth a nation; and Wickedness is the present reproach' ${ }^{9}$ The path away from wickedness was lit by the anti-slavery torch, and Marcus Wood observes in his study of visual representations of slavery that depictions of the anti-slave-trade ships’ recapture and apparent emancipation of slaves bound for the Americas were readily incorporated into providential interpretations of Britain’s abolitionist policies as evidence of the nation's rediscovered righteousness, and its fitness for imperial supremacy. Such imagery fed into ‘the implementation of an abolition myth' that pardoned Britons for 
their past participation in the slave trade by pointing to the self-sacrificing benevolence and moral superiority of their efforts against it. ${ }^{10}$ Having been wrecked against the rocks of the slave trade, in other words, many Britons saw their nation's celestially decreed rescue in the work of the African Squadron. I will proceed to identify how this belief shaped representations of enslaved Africans, naval sailors, and officers, before complicating the picture by examining writings that interpret the death of slaves and naval personnel at sea as evidence of the absence of divine favour for naval elimination of the slave trade.

One narrative that exemplifies what Wood sees as the propensity of British abolitionist discourse to spin self-affirming stories out of the miseries of Atlantic slavery is Mary Sherwood's Dazee; or, the Recaptured Slave (1821). A writer of didactic Christian fiction, Sherwood's firsthand experience of Africa was limited to an excursion at Cape Colony in 1816 during a stopover on a journey to England from India, where she lived with her soldier husband for eleven years. ${ }^{11}$ Apparently the earliest fictionalisation of slave-trade suppression, Dazee was published at a time when detailed information about the African Squadron was confined to the little-known Sierra Leone Gazette, and the annual reports of the African Institution. These contextual details are important in understanding Dazee. A patrician body with strong ties to government that acted 'almost a de facto slave-trade department' until an official Slave Trade Department was established in 1819, the African Institution abandoned the grass-roots campaigning strategies that were used effectively by the anti-slavery bodies in favour of 'gentlemanly politics' at the European congresses held between 1814 and $1820 .{ }^{12}$ Under the supervision of the African Institution, then the Slave Trade Department, naval suppression, above all other anti-slavery causes, was institutionalised and bureaucratised, absorbed into the 'official mind' of the nation, and thus distanced from public support and understanding. ${ }^{13}$ Dazee’s uncomplicated plot spanning the enslavement, recapture, and Christianisation of an African youth is said to derive from a 
Sierra Leone Co. report of 1794, which features a real case of family reunion similar to that of Dazee and his mother. ${ }^{14}$ As such, it reflects the reading public's insulation, in the 1810 s and 1820s, from the difficulties faced by naval crews in rescuing and "repatriating” enslaved Africans. The passage describing the rescue of Dazee and his fellow captives is overloaded with religious imperatives as the liberator calls down into the slave hold, without fear of his auditors' inter-linguistic or inter-cultural incomprehension: 'My brethren, thank God, your deliverance is effected, your enemies and secured, and you shall now be made happy'. ${ }^{15}$ Dazee’s later reunion with his mother--also enslaved and redeemed at sea--is similarly dominated by the need to convert her from the 'abominations and absurdities of heathenism'. ${ }^{16}$ SrinivasAravamudan claims that 'Sherwood conflates deliverance from slavery with spiritual rebirth into Christ. The theme of "Christian son saving superstitious mother" expresses clearly ideological motives of "civilising” the old Africa according to newer evangelical imperatives. ${ }^{17}$ Dazee imparts the religious belief 'that spiritual salvation was the paramount concern of all humans, that worldly affairs were inconsequential', in the words of Moira Ferguson. ${ }^{18}$ Importantly, whereas Newton claimed that his spiritual shipwrecking had enabled his direct communion with God, in Dazee the British naval rescuer stands in as the agent or representative of divine intervention. The hierarchical positioning of humankind beneath God is stratified along lines of race.

Christian redemption is the keynote in numerous missionary reports on naval suppression, including Elizabeth Melville’s, which asserts:

A feeling of patriotic pride always mingles with my pity on seeing a slaver brought in, to think that--thanks to Britain above all other kingdoms on the face of the globe--how soon these, our so unjustifiably oppressed fellow-mortals, will be blessed with a happier freedom than they ever knew in their heathen homes of the far interior. ${ }^{19}$ 
For Melville, naval suppression enabled nationalistic pride as it affirmed her belief in the heathenism of the peoples of West Africa. Christianised liberated Africans similarly conceived of their rescue as a spiritual release from heathenism. The Yoruba Methodist missionary Joseph Wright's short narrative begins with the following extraordinary sentence:

I was born a heathen in a heathen land, and was trained up in my youth to the fashion and customs of that heathenish Country, but the Lord, who would not have me to live to be old in that unhappy Country, brought among us war and confusion as the wages of our sins. ${ }^{20}$

Writings by and about the Yoruba Samuel AjayiCrowther likewise re-inscribe pre-Christian life with Christian convictions. In a similar manner to Wright, Crowther recalls his enslavement as painful, yet 'blessed', for 'Providence had marked out for me to set out on my journey from the land of heathenism, superstition, and vices to a place where His Gospel is preached'. ${ }^{21}$ Recent studies have emphasised the agency of Yoruba-speaking peoples such as the Egba, Ijesha, and Awori who forged a collective 'Yoruba' identity for themselves amid the cultural diversity of Sierra Leone, partly by embracing Christianity. ${ }^{22}$ At the time of publication, however, few readers in Britain were attuned to that diversity. Because his early life bore superficial similarities to that of the fictional Dazee-both, for example, were reunited with mothers who were yet to embrace Christianity following their rescue from the Atlantic crossing and repatriation to Sierra Leone--and despite his giving eloquent testimony as to the fear and confusion of the Atlantic crossing even after it had been reversed by naval intervention, Crowther and his biographers were able to draw clear Christian symbolism from his narrative of redemption, understanding it in straightforward terms as a journey from darkness into light--a case of 'good out of evil'. ${ }^{23}$ 
The flipside of the narrative of the liberated African's conversion to Christianity was its moralising effects upon naval rescuers. Even at the height of the anti-slavery movement in Britain, some commentators believed that common sailors on the anti-slave-trade patrols were not motivated by humanitarian concerns but monetary rewards, or even a simple love of adventure. ${ }^{24}$ Perceiving conflict between financial gain and spiritual health, some questioned whether pecuniary incentives should be necessary in motivating sailors to rescue slaves. ${ }^{25}$ The positive impact upon sailors of service in the African Squadron was nonetheless claimed in popular fictions of the nineteenth century. Conversion generally took the secular form of characters' maturation into readiness for leadership and service in the armed forces. In J.T. Haines’s popular Napoleonic ‘tar drama’ My Poll and My Partner Joe (first performed 1835), for instance, service aboard a Man-of-War during its chase and capture of a slave ship, and contact with black slaves, reconciles a press-ganged sailor, Harry Hallyard, to his duty to King and country. In its first and second acts, until Hallyard rescues the slaves Zinga and Zanga, My Poll and My Partner Joe touches provocatively upon the comparison of the British labourer to the African slave, which, as Catherine Gallagher and others have shown, pervades in much writing by and about the working classes in the early Victorian period, and which prompted some of the more critical representations of naval suppression studied in the following section of this chapter. ${ }^{26}$ Upon being press-ganged, Hallyard declares: 'What! force a man from his happy home, to defend a country whose laws deprive him of his liberty? But I must submit; yet ... I shall strike for the hearts I leave weeping for my absence, without one thought of the green hills or the flowing rivers of a country that treats me as a slave!'. ${ }^{27}$ Yet Hallyard is led to reconsider his self-identification as 'a slave' upon his encounter with the "real” victims of Atlantic slavery. At this point he identifies 'the British flag' as the insignia of freedom, telling the slaves: 'Dance, you black angels, no more captivity, the British flag flies over your head, and the very rustling of its folds knocks every fetter from the limbs of 
the poor slave. ${ }^{28}$ In awakening Hallyard to his imperial duty, and placing the British sailor in a position of kindly but clearly demarcated authority over Africans, My Poll and My Partner Joe prefigures the several boys' own adventures about naval suppression published in the three decades or so following the disintegration of the Atlantic slave trade in the 1860 s. $^{29}$

The credentials of the gentleman-officer too were established in fictions of slave trade suppression. In Charlotte M. Yonge’s family saga The Daisy Chain (1856), one of the main romantic heroes is an officer of the anti-slave-trade squadron, Lieutenant Alan Ernestcliffe. The reader is first introduced to Ernestcliffe from the perspective of his ten-year-old brother, Hector, during the latter's interview with the physician who helps the officer recover from tropical fever. When Dr. May asks Hector if his brother served in the navy, the boy volunteers the following profile:

'Lieutenant Ernestcliffe. He got his promotion last week. My father was in the battle of Trafalgar; and Alan has been three years in the West Indies, and then he was in the Mediterranean, and now on the coast of Africa, in the Atlantis. You must have heard about him, for it was in the newspaper, how, when he was mate, he had command of the Santa Isabel, the slaver they captured.'

The boy would have gone on for ever, if Dr. May had not recalled him to his brother's present condition. ${ }^{30}$

The superfluous mention of Trafalgar connects its heroes to those in West Africa, as if a mantle has been passed from father to eldest son. The young Ernestcliffe's inability to conceal his pride at his brother's efforts is testimony to the emotive part that naval suppression could play in shaping the identities of apparently distant men, women and children--in this case filling an orphaned child with pride in his elder sibling and surrogate 
father. Pride indeed momentarily transports Hector from his present problems as he forgets his brother's illness. And while Dr. May recalls the boy to the here and now by interrupting him, The Daisy Chain nonetheless fills in the picture of Alan Ernestcliffe's heroics, as the doctor subsequently learns from 'other sources' of his patient's distinguished conduct:

in encounters with slave ships, and in command of a prize that he had had to conduct to Sierra Leone, [during which] he had shown great coolness and seamanship, in several perilous conjunctures, such as a sudden storm, and an encounter with another slaver, when his Portuguese prisoners became mutinous, and nothing but his steadiness and intrepidity had saved the lives of himself and his few English compatriots. He was, in fact, as Dr. May reported, pretty much of a hero. He had not, at that time, felt the effects of the climate but, owing to sickness and death among other officers, he had suffered much fatigue... Immediately on his return, had followed his examination, and though he had passed with great credit, and it had been at once followed by well-earned promotion, his nervous excitable frame had been overtasked, and the consequence was a long and severe illness. ${ }^{31}$

As with the Hector's report to the doctor, the detail of Yonge's account of Lt. Ernestcliffe's heroics presumes familiarity with the subject among her audience. Within the parameters of Yonge's domestic novel, service in the African station serves as a short-hand guide to a character's moral trustworthiness.

All of the narratives discussed in this section conceived of the contact zone where slaves met their rescuers as one of powerful moral transformation. Crowther vividly recalls the fear and confusion which attended his first meeting with a naval party(he feared they were cannibals ${ }^{32}$ ), but other authors with less personal experience overlooked such 
difficulties to represent contact in uncomplicated ways that legitimated naval suppression and the political, philosophical and religious imperatives that underlay it. In meeting its generic requirement to entertain and instruct social groups habitually deemed in the nineteenth century to be in need of morally clear-cut explanations rather than difficult truths (women, the working classes, and children), popular and juvenile fiction was particularly amenable to these ends. But the affirmative moralistic interpretation of naval suppression also exists, perhaps more subtly, in non-fictional texts by commentators attributed the cultural capital of high social rank, authority, and seriousness. Lt. Joseph Denman, the son of the Lord Chief Justice and abolitionist Thomas Denman, is one such commentator. As one of the principle agents of the aggressive, in-shore blockading tactics used in West Africa, Denman was a key witness in the parliamentary inquiries into naval suppression policy of the 1840s. Denman's defence of the squadron and his own strong-arm methods depended in part upon the memory of his first-hand experience of the evils of the Atlantic crossing during his service as prizemaster of the Maria de Gloria, a barque captured by HMS Curlew off Rio de Janeiro in November 1833. Of his time in charge of the Maria de Gloria, Denman recalled: 'I was 46 days on that voyage, and altogether 4 months on board her, where I witnessed the most dreadful sufferings that human beings could endure'. ${ }^{33}$ The implication, in his own testimony and in subsequent historical writing, is that Denman's experience aboard the prize compelled his later stance in favour of forcible abolitionism in West Africa and South America. 'Such an initiation into the horrors of the trade bit deep into the young man's mind', writes the naval historian Christopher Lloyd. 'The ruthless methods he subsequently adopted clearly owe their origin to that experience' ${ }^{34}$ Arguments of this kind emerge from the redemptive writings of Newton and subsequent evangelical writers as well as from the more complicated reality of officers' experiences of slave-trade suppression, as documented in this volume by Mary Wills. 
The African Squadron under fire

The morally affirmative representations of naval suppression outlined above did not go unchallenged. Indeed, given that some of the busiest and most dramatic years of slave-trade suppression, in the 1830s and early 1840s, coincided with the popular ascent of the 'nautical novel' penned by the likes of Frederick Marryat, heroic depictions of the African Squadron are strikingly few and far between. Instead this genre tends toward cautionary and outright hostile depictions of the work of rescuing enslaved peoples on the high seas. At the height of the anti-slavery movement of the mid-1830s, abolitionist fanfare was opposed in two novels about the anti-slave-trade squadron written by Michael Scott, Tom Cringle’s Log (1829-33) and The Cruise of the 'Midge' (1834-35). The son of a wealthy Glasgow merchant, Scott spent much of his career as a trader in Jamaica. He maintained personal and business ties to the island's 'white creole' elite after returning to found his own business in Glasgow in 1822. ${ }^{35}$ The two novels he completed before his death in 1835 at age 46 were serialised in the anti-abolitionist Blackwood's Magazine, with Tom Cringle's Log appearing during the passage of the Emancipation Act.

Despite its setting in and immediately after the Napoleonic Wars, Tom Cringle's Log addresses contemporary controversies by opposing emancipation and defending the West Indian planters' way of life. Scott places polemical defences of the planters' rights into the mouths of the novel's most sympathetic characters, and in Chapter XIV, by means of extraordinary prolepsis, he inserts in the narrative a letter sent to the eponymous hero by another main character, the West Indian proprietor Aaron Bang, which criticises abolitionists and outlines a scheme for gradual emancipation of the most able slaves. ${ }^{36}$ Detailed descriptions of post-revolutionary Haiti in ruins, and unrest in the Spanish islands, forebode of the destruction of Britain's colonies, while, in his Byronic soliloquies, Bang portrays himself and his fellow white creoles as romantic castaways of an empire that has abandoned 
them. ${ }^{37}$ On a trip to Haiti, Bang and Cringle escape the island's ruined ports and towns in favour of the untouched forest. There, 'amidst the loneliness of the earth', Bang 'look[s] forward without a shudder, to set up my everlasting rest, to lay my weary bones in the earth, and to mingle my clay with that whereout it was moulded', before likening himself to 'a barbarian' and 'an aboriginal of the land'. ${ }^{38}$ Barbara Lalla interprets passages such as this as Scott's romantic celebration of individual choice, which is forever constrained and contradicted by his dogmatic belief in the racial superiority of whites. ${ }^{39}$ Yet Lalla's argument equates anti-slavery values with autonomy in a way that Scott, and other pro-slavery voices of the 1830s, would have queried. Scott is concerned by the suffocation of the individual who blindly takes up the anti-slavery cause. However distasteful it is to modern-day readers, Scott's romanticism claims bonds of belonging between the white planters and the West Indian soil. It declares the stoic nobility of the West Indian land-owning classes just as these peoples' humanity was questioned by abolitionists and enslaved peoples in Britain and the West Indies.

Other chapters of Tom Cringle's Log dramatise the human costs of slave-trade suppression. Chapter XV features a violent fight between a naval ship and a Spanish slave ship. The battle is won by the former, but not before its gunner fires into the enemy's hold, where the slave traders have taken refuge among their captives. The slave traders then blow up their own vessel in an attempt to kill the raiding naval party on board. All of the slave traders, numerous slaves, and some naval personnel go down with the ship. Of the estimated one hundred and fifty slaves who escape into the water, only eighty-four are rescued; the rest are fired upon by their rescuers in an act of mercy killing:

Soon all was quiet; a wounded black here and there was shrieking in his great agony, and struggling for a moment before he sank into his watery grave for ever; a few 
pieces of wreck were floating and sparking on the surface of the deep in the blood-red sunbeams, which streamed in a flood of glorious light on the bloody deck, shattered hull, and torn rigging of the Wave, and on the dead bodies of and mangled limbs of those who had fallen; while some heavy scattering drops of rain fell sparkling from a passing cloud, as if Nature had wept in pity over the dismal scene; or as if they had been blessed tears, shed by an angel, in his heavenward course ... as he hovered for a moment, and looked down in pity on the fantastic tricks played by ... weak man, in his little moment of power and ferocity. ${ }^{40}$

In the aftermath of the skirmish, bloated black corpses resurface and float alongside the Wave as sea-birds and fishes pick at their flesh. The scene seems designed to meet with William Blackwood's taste for tales of brutality and sensation (as famously lampooned by Edgar Allan Poe. $).^{41}$ It also shares in the Romantic fixation on death at sea, which in turn derives from Shakespeare's 'rich and strange' sea-changes that befall the drowned human body. ${ }^{42}$ The graphic intensity of the shipwreck, with its corporeal gore bathed in an incongruously 'glorious light’, anticipates Turner’s Slave Ship. Yet whereas Turner’s artwork defies reductive decoding, ${ }^{43}$ Cringle and Bang interpret the scene as evidence of the futility of the Wave's attack on the slaver. ${ }^{44}$ Their explanation seems to be shared by the imagined weeping of 'Nature', or the passing angel, which registers a lack of providential support for the cause. Scott's description of the flotsam and jetsam of the sinking slave ship connotes the misguided morality of naval suppression; it is an image to which writers would return amid the attack on naval suppression in 1840s.

The extent of Scott's firsthand knowledge of his subject is uncertain. ${ }^{45}$ It may be that his stories are based on eyewitness reportage of the difficulties of naval suppression that first became available in the annual reports of the African Institution, and which appeared with 
increasing regularity in a variety of forums in the 1830s. A number of these were assembled by Thomas Fowell Buxton in The African Slave Trade and Its Remedy (1839). As it is based on numerous eyewitness accounts, including ones gathered by Buxton in personal correspondence, The African Slave Trade and Its Remedy is probably the most comprehensive mid-nineteenth-century analysis of the slave trade and its eradication. It asserts that naval suppression is failing, and it proposes not only the strengthening of the African Squadron but the extension of Britain's commercial and Christian influence into the West African interior. These civilising forces alone could sever the slave trade at the root, its argument ran. ${ }^{46}$ Recent studies have noted the importance of Buxton's tome in constructing the West African interior as a place of primitive and barbaric rites, reversing the logic of earlier abolitionists such as Thomas Clarkson who believed that inland communities would be more 'civilised' than coastal ones because they were less degraded by contact with Europeans. $^{47}$

As Eltis notes, Buxton also helped solidify a certain image of the post-1808 Atlantic crossing. ${ }^{48}$ He exaggerates the scale of the traffic by claiming that in excess of 150,000 Africans were annually embarked for the Americas, with one quarter dying at sea, and by underlining that atrocities during the oceanic transit of slaves--not least the jettisoning of living cargoes--had been exacerbated as British withdrawal from, then policing of, the traffic, had forced it into the hands of mercenaries. ${ }^{49}$ Economic and demographic historians have since corrected Buxton's calculations as to the volume of the ongoing traffic, ${ }^{50}$ but in the 1840s his work was regarded as authoritative, and the government implemented Buxton's scheme in the form of the naval-led expedition up the River Niger in $1841-42 .{ }^{51}$ One of the ironic outcomes of this disastrous mission was a new batch of narratives detailing the gloomy prospects of current anti-slave-trade measures. These reports would be enlisted in the 
parliamentary appeals of the early and mid-1840s in favour of terminating the West African squadron.

Buxton's tome and the Niger travel narratives that followed it are cautious, sometimes gloomy, on the prospects of slave-trade suppression. But seldom if at all do they call into question justifications of the campaign as a righteous cause. Around the late 1840s, however, new accounts on the difficulties and ironies of the African Squadron undermined the idealism of authors who viewed it in Manichean terms as a question of good and evil, in which the conversion of liberated Africans to Christianity and 'civilisation' made 'good out of evil'. Some writers, in pointing to instances of social deprivation in Britain that the abolitionists overlooked in favour of redeeming Africans bound for the Americas, doubted the exigency of anti-slave-trade policy. This is the tenor of commentaries on the slave trade issued by two intellectual heavyweights of the mid-Victorian era, Thomas Carlyle and Charles

Dickens.Carlyle’s satirical attack on West Indian emancipation and his deployment of crude racial stereotypes in the 'Occasional Discourse on the Negro Question', which first appeared in Fraser's Magazine in 1849, have been frequently discussed in recent literary and cultural studies and need no introduction here. It suffices to note that in its often-overlooked final three paragraphs Carlyle’s speaker attacks the moral and religious argument that elimination of the slave trade is ordained by 'the laws of Heaven': if that is so, he asks, then why not 'go to Cuba and Brazil with a sufficiency of 74-gun ships, and signify to those nefarious countries, that their procedure on the negro question is too bad'? If 'this thing [is] done, the Heavens will prosper all other things with us! Not a doubt of it--provided your premise be not doubtful'. But Carlyle does doubt the premise: he points to the impoverished in Ireland and London to query whether 'the buying of black war-captives in Africa, and bringing them over to the sugar-islands for sale again' is truly 'the most alarming contradiction to the said laws [of this universe] which is now witnessed on this earth'. ${ }^{52}$ 
Dickens's engagement with the slave trade is more sustained than Carlyle’s. Having criticised slavery in the USA in American Notes (1842) and Martin Chuzzlewit (1843-44), in the early 1850s Dickens’s attention was turned to Britain’s anti-slave-trade actions. In late 1850 he published two short stories about the African Squadron in Household Words: Alfred Whaley Cole’s 'Good Intentions: A Story of the African Blockade’, and Franklin Fox and W.H. Wills’s ‘A Cape Coast Cargo’.53 For Grace Moore, Dickens’s publication of these stories 'reveal that he remained supportive of [abolitionism]'. ${ }^{54}$ But Dickens saw slavery in the USA and the international slave trade as separate issues, and, appalled as he no doubt was by the latter, the tales he published are at best ambiguous in their evaluation of the naval patrols. 'Good Intentions', which declares itself to be ‘a true story in every-thing but names', describes the chase of a slave ship that ends with the jettisoning of its cargo. ${ }^{55}$ The incident serves as an illustration of the narrator's introductory remark ' $[t]$ hat the horrors of the passage from Africa to Brazil are often frightfully aggravated by the dread of pursuit and capture by our cruisers' ${ }^{56}$ At the root of the problem was the increasing profitability of the trade, which led slave-ship captains to ever more mercenary tactics in shipping slaves. This was a widely recognised problem of naval suppression since Buxton had publicised it. More provocatively, the narrator of 'Good Intentions' also notes the parallel economic motivation of those who did the chasing: 'Visions of prize-money float before the eyes of every one of the pursuers, from the captain to the cabin boy'. ${ }^{57}$ In noting the irony that human trafficking now afforded opportunities for profit to the naval crews that policed it, the story revisited a source of discomfort for onlookers who maintained that abolition was a moral and spiritual imperative regardless of the economic questions attached to it.

'A Cape Coast Cargo' is the tale of two sailors who unwittingly enlist on a slave-ship, but realise their wrongs and help a British Man-of-War to capture their former crewmates. Even this story of moral redemption stresses that when it comes to naval suppression 'good 
intentions' are in vain, as the slave traders successfully drown their captives en mass prior to their arrest. As with Scott's nautical novels, the spectacle of mass murder at sea is offered up reproachfully as evidence of the uselessness of naval suppression. In the same vein as 'Good Intentions', ‘A Cape Coast Cargo’claims verisimilitude by referring its readers to actual cases to affirm that its plot is not simply 'romance' ${ }^{58}$ Lord Denman appears to have written to Dickens to question his motives for publishing these gloomy stories. Dickens responded by stating: 'I am not satisfied that the African Blockade advances the great end it is designed to promote'. The 'comparative indifference in the public mind' to the government's efforts against the slave trade he attributed to a mounting awareness of 'the many wrongs nearer home, that have to be set right' ${ }^{59}$ In one further, brief reference to the anti-slave-trade squadron in fiction first published by Dickens, the mutiny on HMS Russell that forms the main subplot of Elizabeth Gaskell's North and South (1854-55) is the consequence of cruelty by a captain whose overzealousness is explained by his having previously 'been nearly three years on the station, with nothing to do but keep slavers off, and work [his] men' ${ }^{60}$ The cost to British sailors' lives is weighed against the apparent unimportance of the patrol.

Dickens's next intervention in the debate was his lengthy review of the 'official narrative' of the Buxton-inspired, naval-led expedition up the Niger. The review is largely appreciative of the book and of the efforts of the crews involved. Indeed, the latter are portrayed as brave martyrs to a hopeless cause, for Dickens decried the scheme to eliminate slave trading by delivering European religion and trade into the Niger delta as far-fetched and vainglorious. He contributes to the feminization of humanitarian sentiment in the 1850s and 1860s by ascribing the scheme to 'the weird old women' of 'the Exeter Hall platform' ${ }^{61} \mathrm{He}$ calls the African Squadron 'inefficient and absurd', and, as in his letter to Denman, he concludes that humanitarian 'work at home must be completed' before Britain can hope to enlighten Africa. ${ }^{62}$ Dickens pursued the same argument in Ch. 4 of Bleak House (1852-53), 
‘Telescopic Philanthropy’, in which Ms.Jellyby, the personification of 'the weird old women' of Exeter Hall, frets over the well-being of Africans yet is oblivious to the impoverishment of her own children.This satirical take on the anti-slavery movement was common around the middle of the nineteenth century; Dickens's allegation that the indifference of abolitionists to poverty and exploitation 'at home' amounted to moral hypocrisy is repeated in many forums, ranging from the Times to the Chartists’ Morning Star, and from Uncle Tom's Cabin to some of the several hostile parodies of Harriet Beecher Stowe’s novel. In a Punch cartoon of 1865 that takes its name from Bleak House, Britannia ignores the pleas of street urchins as she looks on at a ship of the African Squadron and an African coastal scene (Figure 6.1).

\section{[Insert Figure 6.1 near here]}

Equally if not more important is the commentary on racial difference in Dickens's Niger review. Much of the text recounts the anti-slave-trade treaty negotiations held between naval officers and three of the region's rulers, King Obi, King Boy and the Attah of Idah. Dickens portrays these as farcical encounters in which the African parties exploit the moral earnestness of their interlocutors to their own pecuniary advantage. To an extent, this was to read against the grain of the report of the encounter, and perhaps to undermine the quasiauthority that European travellers sometimes (though not always) attributed to themselves when making treaties on African soil. For Moore, the most telling aspect of Dickens’s précis is that it 'does not make any generalizations on the subject of race... [T] he evil of the attacks against the missionaries is attributed to King Boy and King Obi as individuals, rather than to a collective race. ${ }^{63}$ But Dickens's representations of African individuals are inescapably informed by his attitudes toward the 'collective race', which are made clear by his references to 'the barbarous African', 'ignorant and savage races', and 'these barbarians'. ${ }^{64}$ Dickens 
credits the potentates with greater awareness of the hollowness of the ceremonial encounters and resultant treaties, yet in doing so he employs King Obi, in particular, in the role of idiot savant--'a savage in a sergeant-major's coat'--whose efforts to enrich himself unveil the absurdity of the Niger mission as a whole. ${ }^{65}$

As with Carlyle’s 'Occasional Discourse’, Dickens’s acerbic prose is illustrative of the new strain of racism which emerged from anthropological and other scientific studies to inform much European writing about people of African descent in the second half of the nineteenth century, and was itself both a symptom and cause of the recession in anti-slavery commitment in that period. ${ }^{66}$ Indeed, it was in protest against a sentimental woodcut illustration of liberated Africans in Sierra Leone which appeared in Transactions of the Ethnological Society of 1863 that James Hunt founded the Anthropological Society of London. ${ }^{67}$ In harnessing new theories of race actively to confront evangelical notions of the oneness of human kind by holding that Africans were of a different and inferior species to Europeans, the Anthropological Society attacked the evangelical and moral justifications of abolitionism in general, and the naval patrol—which its most famous member, the explorer Richard F. Burton, dubbed 'the Sentimental Squadron' ${ }^{68}$ —in particular. Burton's attitude toward the antislavery movement is encapsulated in his assertion in Mission to Gelele (1864) that the 'kneeling negro' in the famous anti-slavery icon titled 'Am I Not a Man and a Brother?', 'properly speaking, should have been on all fours', such is his bestiality. ${ }^{69}$ Burton proposed forced emigration of African 'recaptives' to the British West Indies: it 'is like sending a boy to school. It is his only chance of improvement. ${ }^{70}$ While Burton distinguished his plan from the proslavery arguments of old, it is nonetheless clear that the new racial sciences took debate on the slave trade almost entirely full circle, to a position from which a recapitulation of something akin to that traffic seemed, to a small and vocal minority, a reasonable solution. 


\section{Conclusion}

The written representations surveyed in this chapter complicate Patrick Brantlinger's claim that '[i]n British literature from about 1830 to the 1870s, white heroes rarely doubt their ability to tame various geopolitical mistresses—Africa, the sea, the world — and to bring civilized order out of the chaos of savage life. ${ }^{71}$ They do so by demonstrating the diversity of perspectives on slave trade suppression while it remained a burning issue in British political, social and humanitarian debates. As they imagined or recalled the work of the patrolling squadrons, one writer's evidence of absurd wastefulness and hypocrisy was another's proof of worthy sacrifice for a supreme cause. The religious and moralistic justifications of the campaign in particular were fiercely disputed, and this resulted in markedly different depictions of the chase and capture of slave ships, and the Africans they transported toward the Americas. Only in the latter decades of the nineteenth century, following the removal of the squadron and the eradication of the Atlantic slave trade, was consensus reached as to the moral righteousness of the campaign. Then writers of boys’ own adventures such as W.H.G. Kingston and R.M. Ballantyne regaled new generations of readers with stories of young naval officers' daring conquest of slave-trading pirates and African savages. ${ }^{72}$ Although some of these tales were ostensibly set at the height of the anti-slave-trade cruises in the 1830s, their bluster and bloodthirstiness betray that they are a product of the late-Victorian desire for and confidence in Britain's right not only to end slavery but to rule in Africa. Between 1830 and 1860, few publications regarded the situation with such surety. In nineteenth-century Britain, the African Squadron's part in prolonging the culture of anti-slavery seemed at its most apparent in retrospect.

One thing that unites most of the writing about the anti-slave-trade patrols is its seeming lack of interest in the agency of enslaved Africans and liberated Africans. Shipboard insurrections continued to take place throughout the period of naval suppression, but seldom 
are they reported in detail, if at all, in British publications. ${ }^{73}$ This is in contrast to the body of fictions of slave-ship rebellion produced by the US authors Herman Melville, Frederick Douglass, William Wells Brown, Lydia Maria Child, and Martin Delaney. ${ }^{74}$ Similarly, besides certain missionaries, the efforts of former slaves who made successful lives for themselves in Sierra Leone were little known outside of the colony. It is hard to disagree with Wood's verdict that abolitionists of the nineteenth century conceived of freedom for enslaved peoples as a boon when granted by kindly white patrons, under certain conditions, rather than autonomously seized by those peoples. ${ }^{75}$ At the same time it is important to understand this tendency to assert moral righteousness in the broader ideological and discursive context in which the benefits of emancipation were contested, indeed openly questioned, by writers of great influence and popularity.

Notes

1 J. Gallagher, 'Fowell Buxton and the New African Policy 1838-42', Cambridge Historical Journal, 10 (1950), 36-58.

2 The focus of this chapter is upon written materials published in British media. Marcus Wood discusses visual representations in Blind Memory: Visual Representations of Slavery in England and America, 1780-1865(Manchester: Manchester University Press, 2000), pp. 7-8. Unpublished literary materials feature in Ch. 4 of the present volume.

3 For a useful summary of first-hand, nonfictional accounts, see Philip D. Curtin, The Image of Africa: British Ideas and Actions, 1780-1850 (Madison, WI: University of Wisconsin Press, 1964), p. 322.

4 Tim Fulford, 'Romanticizing the Empire: The Naval Heroes of Southey, Coleridge, Austen, and Marryat', MLQ: Modern Language Quarterly, 60 (1999): 161-196. 
5Margarette Lincoln, 'Shipwreck Narratives of the Eighteenth and Early Nineteenth Century: Indicators of Culture and Identity’, Journal for Eighteenth-Century Studies, 20 (1997), 15572; Carl Thompson, The Suffering Traveller and the Romantic Imagination(Oxford: Oxford University Press, 2007); Matthew Rubery, The Novelty of Newspapers: Victorian Fiction after the Invention of the News(Oxford: Oxford University Press, 2009), pp. 23-45.

6 John Newton, Thoughts on the Slave Trade (1788), in Slavery, Abolition and Emancipation: Writings in the British Romantic Period. Vol. 2: The Abolition Debate, ed. Peter J. Kitson (London: Pickering and Chatto, 1999), pp. 77-117, p. 79. Further quotations of Newton refer (in parenthesis) to this edition.

7 Newton, Thoughts, p. 83.

8 On the slave trade as national sin, see Linda Colley, Britons: Forging the Nation, 17071837 [1992](London: Pimlico, 2003), p. 353.

9 Newton, Thoughts, p. 82.

10 Wood, Blind Memory, pp. 7-8.

11 Moira Ferguson, 'Fictional Constructions of Liberated Africans: Mary Butt Sherwood', in Tim Fulford and Peter J. Kitson (eds), Romanticism and Colonialism: Writing and Empire, 1780-1830(Cambridge: Cambridge University Press, 1998), pp. 148-163, p. 151.

12 David Eltis, Economic Growth and the Ending of the Transatlantic Slave Trade(Oxford: Oxford University Press, 1987), p. 105. See Wayne Ackerson, The African Institution (18071827) and the Antislavery Movement in Great Britain (Lewiston, NY: Edwin Mellen Press, 2005), p. 105. Only in its petition campaign to compel the government to seek an immediate end to the French slave trade did the African Institution break with its own elitist approach. This appeal, which acquired three-quarters of a million men’s and women's signatures over 800 petitions, played its part in the establishment of a permanent West African Squadron, from 1818. According to Turley, it was the only occasion on which the continuing slave trade 
intruded into public debates until the end of the campaign for abolition of slavery in the British colonies in 1838. David Turley, The Culture of English Antislavery, 1780-1860 (London: Routledge, 1991), p. 65.

13 Roger Anstey, 'The Pattern of British Abolitionism in the Eighteenth and Nineteenth Centuries’, in Christine Bolt and Seymour Drescher (eds), Anti-Slavery, Religion, and Reform: Essays in Memory of Roger Anstey (Folkestone, Kent: Dawson, 1980), pp. 19-42, quotation at p. 33.

14SrinivasAravamudan, 'Mary Sherwood, Dazee; or, The Recaptured Slave (1821)’, in SrinivasAravamudan(ed.), Slavery, Abolition and Emancipation: Writing in the British Romantic Period. Vol. 6: Fiction (London: Pickering and Chatto, 1999), pp. 327-8, quotation at p. 328.

15Mary Sherwood, Dazee; or, The Recaptured Slave [1821], in SrinivasAravamudan(ed.), Slavery, Abolition and Emancipation: Writing in the British Romantic Period. Vol. 6: Fiction (London: Pickering and Chatto, 1999), pp. 329-69, quotation at p. 358.

16 Sherwood, Dazee, p. 363.

17Aravamudan, 'Mary Sherwood', p. 328.

18 Ferguson, ‘Fictional Constructions’, p. 153.

19 Elizabeth Melville, A Residence at Sierra Leone (London: John Murray, 1849), pp. 135-6. 20 Joseph Wright, 'The Narrative of Joseph Wright' [Ms. 1839; 1841], in Philip D. Curtin, ed. Africa Remembered: Narratives by West Africans from the Era of the Slave Trade (Madison, WI: University of Wisconsin Press, 1968), pp. 322-33, quotation at p. 322. 21 Samuel AjayiCrowther, ‘The Narrative of SamuelAjayiCrowther’ [1837], J.F. Ade Ajayi (ed.), in Africa Remembered, pp. 298-316, quotation at p. 299. 
22 J.D.Y. Peel, Religious Encounter and the Making of the Yoruba (Bloomington: Indiana University Press, 2001); David Northrup, ‘Becoming African: Identity Formation among Liberated Slaves in Nineteenth-Century Sierra Leone', Slavery and Abolition 27 (2006), 1-21. 23 A.F.C., Good Out of Evil; or, The History of Adjai, The African Slave Boy [1850] (London: Wertheim and Macintosh, 1852).

24 For example, Peter Leonard, Records of a Voyage to the Western Coast of Africa, and of the Service on that Station for the Suppression of the Slave Trade, in the Years 1830, 1831, and 1832 (Edinburgh: William Tait, 1833), pp. 131-32.

25 Macgregor Laird and R.A.K. Oldfield, Narrative of an Expedition in the Interior of Africa by the River Niger, 2 vols.(London: Richard Bentley, 1837), ii. 367-68; Anon., 'Prefatory Remarks to the Present Edition', in Thomas Clarkson, History of the Rise, Progress, and Accomplishment of the Abolition of the African Slave Trade by the British Parliament [1808] (London: John W. Parker, 1839), pp. 1-32, pp. 4-7.

26 Catherine Gallagher, The Industrial Reformation of English Fiction: Social Discourse and Narrative Form, 1832-1867 (Chicago: University of Chicago Press, 1985), pp. 3-35.

27 John Thomas Haines, My Poll and My Partner Joe: A Nautical Drama in Three Acts (London: John Cumberland, n.d.), p. 23.

28 Haines, My Poll and My Partner Joe, p. 33. For further analysis, see Robert Burroughs, 'Sailors and Slaves: “The Poor Enslaved Tar” in Naval Reform and Nautical Melodrama', Journal of Victorian Culture 16 (2011), 305-323.

29 See Catherine Gallagher, 'Floating Signifiers of Britishness in the Novels of the AntiSlave-Trade Squadron', in Wendy S. Jacobson, (ed.), Dickens and the Children of Empire (Basingstoke, Hampshire: Palgrave, 2000), pp. 78-93.

30 Charlotte M. Yonge, The Daisy Chain; or, Aspirations [1856] (London: Virago, 1988), p. 9. 
31Yonge, The Daisy Chain, pp. 9-10.

32Crowther, ‘Samuel AjayiCrowther’, p. 313.

33Qtd. in Christopher Lloyd, The Navy and the Slave Trade [1949] (London: Frank Cass, 1968), p. 93. See also Joseph Denman, Practical Remarks on the Slave Trade (London: J. Ridgway, 1839, 2nd ed.), pp. 17-21.

34 Lloyd, The Navy and the Slave Trade, p. 93.

35 On 'white creole' culture and identity, see David Lambert, White Creole Culture, Politics and Identity During the Age of Abolition (Cambridge: Cambridge University Press, 2005); ChristerPetley, 'Slavery, Emancipation and the Creole Worldview of Jamaican Colonists, 1800-1834', Slavery and Abolition 26 (2005), 93-114.

36 For examples of the explicit defence of planters’ rights, see Michael Scott, Tom Cringle's Log [1829-33] (New York: Henry Holt, 1999), pp. 132, 148, 255, 399, 422; for the letter from Bang, pp. 354-8.

37 Scott, Tom Cringle’s Log, pp. 278-9.

38 Scott, Tom Cringle’s Log, p. 460.

39 Barbara Lalla, 'Dungeons of the Soul: Frustrated Romanticism in Eighteenth and Nineteenth-Century Literature of Jamaica’, MELUS 21, 3 (1996), 2-23.

40 Scott, Tom Cringle’s Log, pp. 387-8.

41 Edgar Allan Poe, ‘How to Write a Blackwood Article’ [1838], in Poe, Complete Tales and Poems (Ljubjlana: MladinskaKnjiga, 1966), pp. 302-12.

42William Shakespeare, The Tempest, Virginia Mason Vaughan and Alden T. Vaughan (eds) (London: Arden Shakespeare, 2003), p. 178 (Act 1, Scene 2, lines 397-402 ). On

Romanticism and suffering at sea, see Thompson, The Suffering Traveller.

43 Wood, Blind Memory, pp. 41-68.

44 Scott, Tom Cringle’s Log, pp. 391-3. 
45 See Eugene A. Nolte, 'Michael Scott and Blackwood’s Magazine: Some Unpublished Letters', Library, 8 (1953), 188-96.

46ThomasFowell Buxton, African Slave Trade and its Remedy (London: John Murray, 2nd edn, 1840).

47Patrick Brantlinger, Rule of Darkness: British Literature and Imperialism, 1830-1914 [1988] (London: Cornell University Press, 1990), p. 177; William Pietz, 'The Fetish of Civilization: Sacrificial Blood and Monetary Debt', in Peter Pels and Oscar Salemnick (eds), Colonial Subjects: Essays on the Practical History of Anthropology (Ann Arbor: University of Michigan Press, 1999), pp. 53-81.Thomas Clarkson, Cries of Africa, to the Inhabitants of Europe (London: Harvey And Darton, 1822), p. 18.

48Eltis, Economic Growth, p. 126.

49 Gallagher, ‘Fowell Buxton’, p. 41. The geographer James MacQueen, who advised Buxton on his 'remedy', likewise claimed with hyperbole that since abolition the slave trade had tripled 'in amount, and besides in horrors tenfold!!' .A Geographical Survey of Africa (London: B. Fellowes, 1840), p. xxiii.

50 David Eltis, 'The Volume and Structure of the Transatlantic Slave Trade: A Reassessment', The William and MaryQuarterly 58 (2001), 17-46.

51 See Howard Temperley, White Dreams, Black Africa: The Antislavery Expedition to the Niger (London: Yale University Press, 1991).

52 Carlyle’s article was republished as a pamphlet in 1853 under the new and more provocative title 'Occasional Discourse on the Nigger Question'. It is reproduced under this title in The Works of Thomas Carlyle, 30 vols.(London: Chapman and Hall, 1899), xxix. 34883. Quotations at xxix. 381-3. 
53Alfred Whaley Cole, 'Good Intentions: A Story of the African Blockade’, Household Words, 5 October 1850, 45-7; Franklin Fox and W.H. Wills, 'A Cape Coast Cargo', Household Words, 7 December 1850, 252-7.

54 Grace Moore, Dickens and Empire: Discourses of Class, Race and Colonialism in the Works of Charles Dickens (Aldershot, Hampshire: Ashgate, 2004), p. 55.

55 Cole, ‘Good Intentions’, p. 45. The tale is set in the Mozambique Channel, in the Indian Ocean, but this had been a subsidiary source for slaves in the Atlantic slave trade since the 1810s, and the narrator frames the tale with references to the Atlantic trade.

56 Cole, ‘Good Intentions’, p. 45.

57 Cole, ‘Good Intentions’, p. 45.

58 Fox and Wills, ‘Cape Coast Cargo’, p. 256.

59Dickens to Denman, 16 December 1850, inGraham Storey, Kathleen Tillotson and Nina Burgis(eds)The Letters of Charles Dickens, 12 vols. (Oxford: Clarendon, 1987), vi. 236-7. 60 Elizabeth Gaskell, North and South (London: Penguin Classics, 2007), pp. 124-5. 61Charles Dickens, ‘The Niger Expedition’, Examiner, 19 August 1848, 45-63, quotation at p. 45. On the mid-Victorian attack on humanitarian sentiment, see Douglas A. Lorimer, Colour, Class and the Victorians: English Attitudes to the Negro in the Mid-Nineteenth Century(Leicester: Leicester University Press, 1978), pp. 113-4, 121.

62Dickens, ‘Niger Expedition’, pp. 55, 63.

63Moore, Dickens and Empire, p. 69.

64Dickens, ‘Niger Expedition’, pp. 62, 63.

65 Dickens, 'Niger Expedition’, pp. 49-57, quotation at p. 55.

66 See Lorimer, Colour, Class and the Victorians, pp. 131-61. On Dickens’s later embroilment in the controversies which surrounded publication of Harriet Beecher Stowe's best-selling anti-slavery novel Uncle Tom’s Cabin, see Harry Stone, 'Charles Dickens and 
Harriett Beecher Stowe', Nineteenth-Century Fiction, 12 (1957), 188-202; Sarah Meer, Uncle Tom Mania: Slavery, Minstrelsy, and Transatlantic Culture in the 1850s (Athens, GA:

University of Georgia Press, 2005), pp. 204-7.

67 George W. Stocking, Jnr., Victorian Anthropology (New York: The Free Press, 1987), p. 376.

68Richard F. Burton, A Mission to Gelele, King of Dahome [1864, 2 vols.] (London: Tylson and Edwards, 1893), i. 5.

69Burton, Mission to Gelele, ii. 122n2.

70 Burton, Mission to Gelele, ii. 136.

71Brantlinger, Rule of Darkness, p. 44.

72 For commentary and further references see Gallagher, 'Floating Signifiers’.

73 See Eric Robert Taylor, If We Must Die: Shipboard Insurrections in the Era of the Atlantic Slave Trade (Baton Rouge: Louisiana State University Press, 2006), pp. 210-13.

74 See Maggie Montesinos Sale, The Slumbering Volcano: American Slave Ship Revolts and the Production of Rebellious Masculinity (Durham: Duke University Press, 1997); CelesteMarie Bernier, ““Arms Like Polished Iron”: The Black Slave Body in Narratives of a Slave Ship Revolt', in Thomas Wiedemann and Jane Gardner (ed.), Representing the Body of the Slave (London: Frank Cass, 2002), pp. 91-106; GesaMackenthun, Fictions of the Black Atlantic in American Foundational Literature (New York: Routledge, 2004), pp. 89-102. 75 Marcus Wood, Slavery, Empathy, and Pornography (Oxford: Oxford University Press, 2002); Wood, 'Emancipation Art, Fanon and the Butchery of Freedom’, in Brycchan Carey and Peter J. Kitson (eds), Slavery and the Cultures of Abolition(Cambridge: D.S. Brewster, 2007), pp. 11-41. 